\title{
PESTICIDES AND INDIAN AGRICULTURE- A REVIEW
}

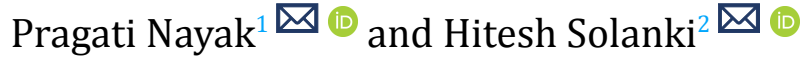 \\ ${ }^{1}$ PhD Research scholar, Department of Environment science, School of Sciences, Gujarat University, Ahmedabad, India \\ ${ }^{2}$ Professor and Coordinator, Department of Botany and Environment science, School of Sciences, Gujarat University, \\ Ahmedabad, India
}

Received 4 May 2021

Accepted 19 May 2021

Published 31 May 2021

Corresponding Author

Pragati Nayak, pragatinyk@gmail. com

DOI 10.29121/

granthaalayah.v9.i5.2021.3930

Funding: This research received no specific grant from any funding agency in the public, commercial, or not-for-profit sectors.

Copyright: (C) 2021 The Author(s). This is an open access article distributed under the terms of the Creative Commons Attribution License, which permits unrestricted use, distribution, and reproduction in any medium, provided the original author and source are credited.

\section{ABSTRACT}

Globally more than half of the pesticides are utilized in Asia. India stands $12^{\text {th }}$ in pesticide use globally and 3rd in Asia after China and Turkey. In present study, the data of different types of pesticides, pesticide use pattern and detailed pesticide consumption of the India and world were collected, organized and summarized. Around $70 \%$ of the total population is employed under agriculture sector which is the most important sector of Indian economy. And pesticides and fertilizers are major integral part of modern agriculture. Commonly used pesticides includes insecticides, fungicides and herbicides for management of uncontrolled weeds and pests on agricultural sites. However in total pesticide consumption, insecticides occupies highest share in India. India share only $1 \%$ of the global pesticide use. As per the data of FAO, India has utilized around 58160 tonnes of pesticide in 2018. Per hectare application rate of pesticide was only $0.31 \mathrm{~kg}$ in 2017 . While consumption in China, Japan and America was around $13.07,11.76$ and $3.57 \mathrm{~kg} \mathrm{ha}^{-1}$ of pesticides respectively. So it is clear that India applies less amount of pesticides in per hectare of cropland area, but uncontrolled and haphazard pesticide usage is responsible for the presence of high pesticide residues in both natural and physical environment. Bio-pesticides have proven to be the finest alternative to chemical pesticides for promoting a sustainable method of development in the agriculture sector, while also reducing pollution caused by chemical pesticides. Many biopesticides are now being developed in India and could be excellent alternatives to chemical pesticides. There are many eco-friendly plant based and microbial bio-pesticides available in the market. Bio-pesticides consumption is only $8 \%$ in India. For sustainable agricultural development and to protect environment from adverse effect of chemical pesticides, formulation and utilization of biopesticides should be prompted.

Keywords: Pesticides, Chemical Pesticides, Bio-Pesticides, Indian Agriculture 


\section{INTRODUCTION}

Pesticides are substances (natural or manmade) used to control pests, weeds, and diseases in plants in various agronomic practices. Herbicides, insecticides, fungicides, rodenticides, nematicides, and other pesticides are examples of pesticides. The losses of crops caused by insect pests are quite high in both developing and developed countries Dhaliwal et al. (2015). Reduced crop loss will be a key component, and enhanced pest management, including diseases and weeds, will require significant effort. Pesticides have become a key tool for plant protection and improvement of crops in the process of agricultural development. A. Sharma et al. (2019) . Pathogens and pests are causing global wheat losses ranging from $10 \%$ to $28 \%$, rice losses ranging from $25 \%$ to $41 \%$, maize losses ranging from $20 \%$ to $41 \%$, potato losses ranging from $8 \%$ to $21 \%$, and soybean losses ranging from $11 \%$ to $32 \%$, according to a study published in the journal Nature, Ecology \& Evolution. Savary et al. (2019). The intensity of protection for crops, as shown by a 15-20-fold increase in pesticides used around the world, has increased significantly in order to make agriculture more productive and profitable. Despite a clear increase in pesticide use, crop losses have not decreased significantly over the last 40 years. OERKE (2006).

Food, feed, fibre, biofuel, and other bio-based goods are in high demand, and agriculture must meet it. An increase in population size in developing countries is forecast to raise food production demand by $70 \%$ in view of shifts in dietary trends towards high-quality food, e.g. increased meat and dairy intake, and increased use of kernels for livestock feed Popp et al. (2013). The world population also increased from 1.65 billion to 7.7 billion throughout the twentieth century alone Green (2018); Nations (2019). Moreover, the world population is predicted to expand to about 8.5 billion by 2030, 9.7 billion in 2050 and 10.9 billion in 2100 Nations (2019).

Pesticides are used to increase agricultural productivity, but they are used indiscriminately and pollute the biota. Non-target species are harmed as a result of pesticide transfer in the environment. Some insecticides have the potential to harm human health and the environment. Only around 0.1 percent of pesticides are believed to reach the intended organisms, with the rest polluting the environment and causing environmental harm Carriger et al. (2006); Gill and Garg (2014).

A closer look at pesticide use finds that we're using more pesticides and treating crops more frequently than ever before. Global pesticide use (in tonnes of active ingredient) increased by 46\% between 1996 and 2016, according to the FAOSTAT database WHO (2019). Pesticides work by causing harm to the creatures they target. However, pesticides do not function in the same way for every species. They also have an impact on non-target species. Organophosphate, carbamate, and pyrethroid insecticides are the most often used pesticides Gilbert (2012). Currently, around four million tonnes are used per year on a global basis, most of which are herbicides (56\%), followed by insecticides (19\%), fungicides (25\%) and other types such as rodenticides and nematicides FAO (2018). 
This literature review firstly provides basic scientific information about the classification of pesticide in use and pesticides usage pattern in India and world. The review shows the current scenario of pesticide usage pattern in Indian agriculture.

\section{CLASSIFICATION OF PESTICIDES}

Diverse criteria are used to describe the pesticides, for example, their toxicity, pest organisms that are killed and their functioning as pesticides, chemical composition and route of entrance, mode of action, how or when it works, formulations and sources of origin I. Yadav and Devi (2017); Akashe et al. (2018); Freedman (2018); Hassaan and Nemr (2020); Nayak et al. (2020); Tudi et al. (2021).

1. Classification of pesticides according to its toxicity: Pesticide toxicity is primarily determined by two factors: dose and time. Thus, the amount of this chemical (dose) is involved and how often (time) the material is exposed to lead to two different kinds of toxicity, acute and chronic.

\begin{tabular}{|c|c|c|c|}
\hline \multicolumn{2}{|c|}{ WHO Class } & \multicolumn{2}{|c|}{$\begin{array}{l}\mathrm{LD}_{50} \text { for rats (mg/kg of body } \\
\text { weight) }\end{array}$} \\
\hline & & Oral & Dermal \\
\hline Class- $\mathrm{I}_{a}$ & Extremely Hazardous & Less than 5 & Less than 5 \\
\hline Class- $\mathrm{I}_{b}$ & Highly Hazardous & 5 to 50 & 5 to 200 \\
\hline Class-II & Moderately Hazardous & 50 to 2000 & 200 to 2000 \\
\hline Class-III & Slightly Hazardous & Over 2000 & Over 2000 \\
\hline Class-V & Unlikely to present acute hazard & \multicolumn{2}{|c|}{5000 or higher } \\
\hline
\end{tabular}

2. Classification of Pesticides according to Chemical Composition : This is the most popular and useful way of pesticide classification based on chemical makeup. Pesticides such as insecticides, fungicides, herbicides, and rodenticides are also classed based on their chemical compositions, as shown below:

Insecticides: Insecticides are classed chemically as Carbamates (Carbaryl), Organochlorine (Endosulfan), Organophosphorus (Monocrotophos), Pyrethroids (permethrin), Neonicotinoids (Imidacloprid), various pesticides such as Spinosyns (Spinosad), Benzolureas (diflubenzuron), Antibiotics (abamectin),

Fungicides: Fungicides are categorised as aliphatic nitrogen fungicides (dodine), amide fungicides (carpropamid), aromatic fungicides (chlorothalonil), dicarboximide fungicides (famoxadone), dinitrophenol fungicides (dinocap), and others.

Herbicides: Herbicides include anilide herbicides (flufenacet), phenoxyacetic herbicides (2, 4-D), quaternary ammonium herbicides (Paraquat), chlorotriazine herbicides (atrazine), sulfonylurea herbicides (chlorimuron), and others.

Rodenticides: Rodenticides are classed as inorganic rodenticides (Zinc phosphide, Aluminium Phosphide) or organic coumarin rodenticides (bromadiolone, coumatetralyl) 
3. Classification of pesticides based on the pest organism they kill and pesticide's functionality (Use): Pesticides are characterized in this way based on the pest organisms they kill and their functions. Different type of pesticides are mentioned below:

Insecticides are chemicals that are used to kill insects and other arthropods. Fungicides are chemicals that kill fungi. Acaricides are pesticides that kill mites and ticks. Algicides are chemicals that kill or suppress algae. Herbicides are chemicals that are used to kill undesired plants. Antifeedants are chemicals that stop insects and other pests from eating. Avicides are poisonous chemicals used to kill birds. Bactericides are substances that kill or inhibit bacteria. Larvicides stop larvae from growing. Repellents are substances that repel bugs based on their taste or odour. Dessicants work by drying the tissues of plants. Virucides are antiviral agents. Ovicides inhibits the growth of insect and mite eggs. Nematicides are chemicals that kill nematodes, which are plant parasites. Termiticides are chemicals that kill termites. Chemicals that make an insect sterile and hence prevent it from reproducing are known as chemosterillants. Plant growth regulators are substances that affect the expected rate of plant growth, flowering, or reproduction.

4. Classification of pesticides based on Mode of Entry: Pesticide modes of entry refer to the various ways pesticides come into touch with or enter the target.

1. Systemic pesticides: pesticides absorbed into and transported to untreated tissue by plants and animals. 2, 4-Dichlorophenoxyacetic acid (2, 4-D) and glyphosate are both examples of systemic insecticides.

2. Contact (non-systemic) pesticides: When target pests come into contact with them, the pesticide acts on them. Paraquat and diquat dibromide, both contact insecticides, are examples.

3. Stomach poisons: These toxins enter the body of the pest through the mouth and digestive system. Malathion is one example.

4. Fumigants: Pesticides that kill or may kill target pests by creating vapour and entering the pest's body through the trachea.

5. Repellents: Repellents do not kill but they are disgusting enough to keep them away. The capacity of the pesticide to locate a crop also interferes.

5. Classification of $\mathbf{p}$ esticides by mode of action: various pesticides have various mode of action. And pesticides are categorised as following according to mode of action

1. Physical poison: Pesticides kill an insect with a physical effect

2. Protoplasmic poisons: protein precipitation is caused by pesticides

3. Respiratory poison: chemical substances which are respiratory enzymes that are in-active 
4. Nerve poison: Chemicals block the transmission of impulses

5. Inhibition of chitin: Compounds hinder synthesis of chitin in pests

6. Classification based on sources of origin: Pesticides are divided into two categories: bio-pesticides and chemical pesticides, depending on their source of origin.

Organochlorine, organophosphate, carbamate, and pyrethroid pesticides are further classified into organochlorine, organophosphate, carbamate, and pyrethroids, as explained in the previous section.

Pesticides originating from natural sources such as animal, plant, and microorganisms are known as bio-pesticides (bacteria, viruses, fungi, and nematodes). They are divided into three categories.

1. Microbial pesticides: They are a type of pesticide that is produced by microorganisms Microorganisms such as bacteria, fungi, and protozoa are the active ingredient in microbial pesticides. These pesticides kill insects by releasing poisons produced by microbiological organisms or infecting them.

2. Plant-incorporated pesticides: These pesticides are naturally produced by plants. In addition, genetic engineering is used to insert the gene required for pesticide production into the plant. As a result, the pesticide produced by such a plant, as well as the genetic material injected, are referred to as plant integrated protectants (PIPs).

3. Biochemical pesticides: These are natural compounds with nontoxic pest control processes. Insect sex pheromones (which interfere with mating) and a variety of fragrant plant extracts are examples of biochemical insecticides (work by attracting insect pests into traps).

\section{PESTICIDE USAGE PATTERN}

There are 293 pesticides registered in India, and it is reported that 104 pesticides are still being produced/used in the country despite being prohibited in two or more nations around the world Goi (2021). Out of total insecticides used for pest management in India, 50\% are diverted to cotton pest management Mooventhan et al. (2020).

Due to over dependence and indiscriminate use of insecticides, many ill-effects including residue in plant parts, resistance to insecticides, secondary pest out-break, pollution to natural resources, health complications for human and wildlife etc., warrant to switch over to eco-friendly pest management methods Birthal and Sharma (2004). In 2017 the Indian use is low, compared to $19.6 \mathrm{~kg}$ per ha in Saint Lucia, 16.59 in Hong Kong, 13.9 in Ecuador, 13.3 in Taiwan and 13.07 in China, at about $0.31 \mathrm{~kg}$ per ha of pesticide. America has reduced its use by $2.54 \mathrm{~kg}$ per hectare Roser (2019) .

Pesticide usage patterns in India differ from those in the world as a whole (Figure 1). In India, insecticides, fungicides, and herbicides are used. Insecticides 


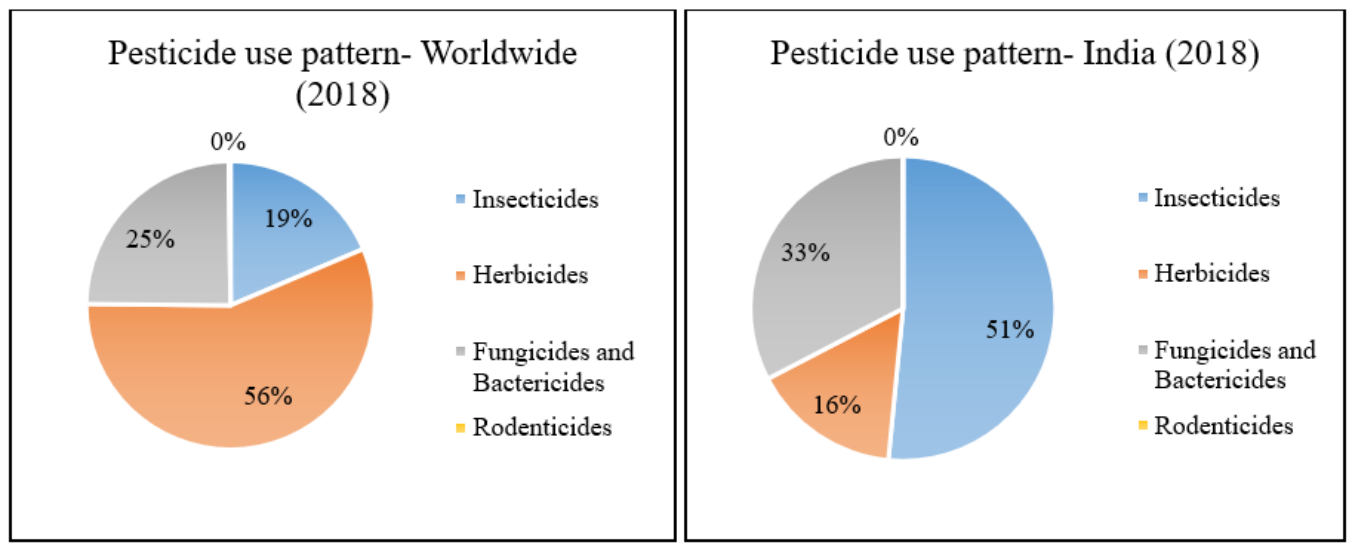

Figure 1 Pesticide use pattern- Worldwide and India (Source: http://www.fao.org/faostat/en/\#d ata) FAO (2018)
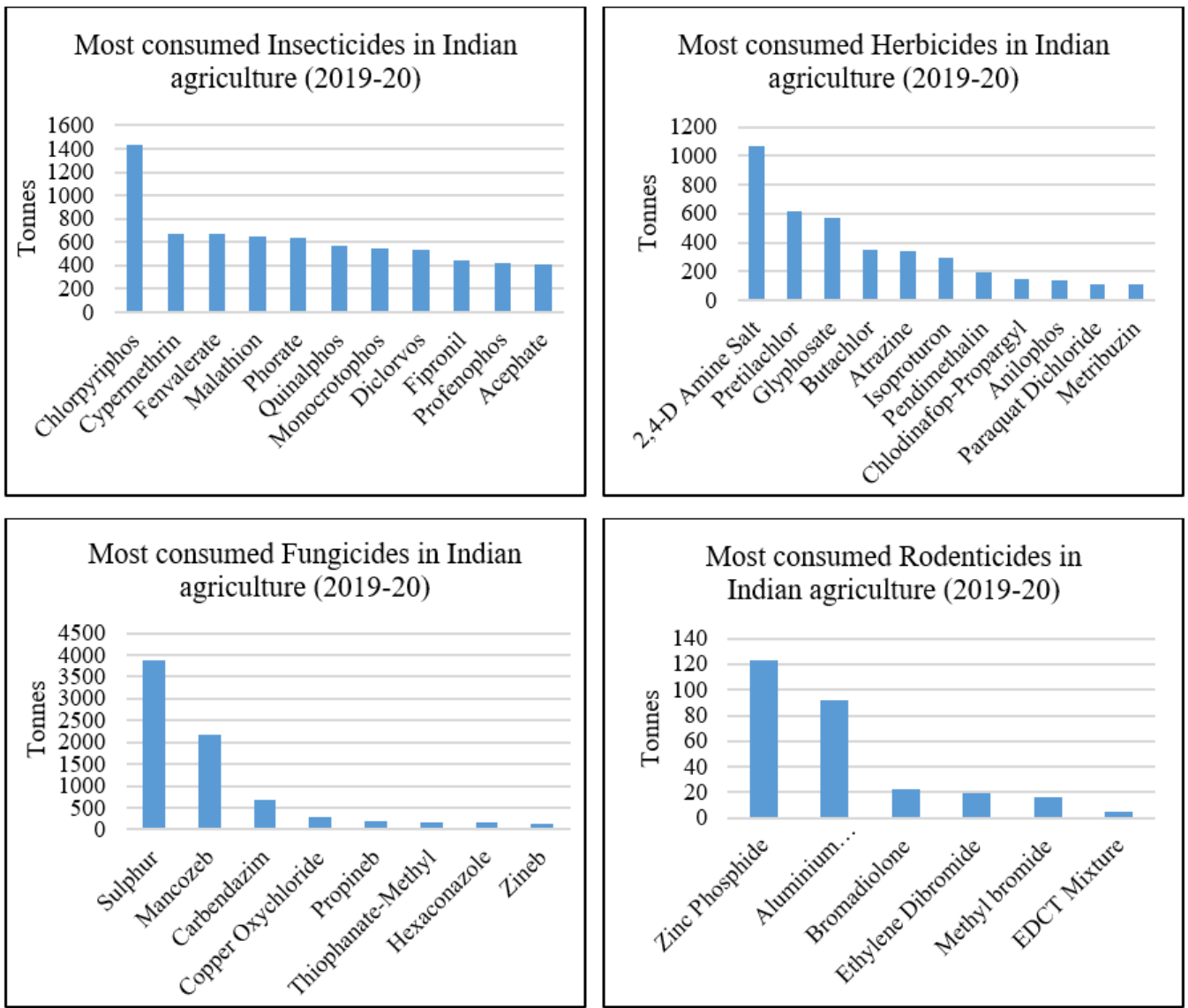

Figure 2 Most consumed Insecticides, herbicides, fungicides and rodenticides during 2019-20 in India 2019-20 in India

(Source: Ministry Of Agriculture \& Farmers Welfare, \$) 
account for the majority of the total. The present pesticide use pattern in India is insecticides $>$ herbicides $>$ fungicides+bactericides $>$ other-pesticides, whereas the global pesticide use pattern is herbicides $>$ fungicides+bactericides $>$ insecticides $>$ otherpesticides. Currently, India is the world's fourth largest producer of pesticides. The Indian pesticides industry was worth Rs 214 billion in 2019, according to Research and Markets. The market is expected to reach Rs. 316 billion by 2024, with a compound annual growth rate of 8.1 percent. TAAS (2020).

Chlorpyriphos is the most widely used insecticide pesticide (Figure 2 ). Its consumption has risen from 471 MT in 2014-15 to 1431 MT in 2019-20. Sulphur is the most often used fungicide, with a consumption of 1548 MT in 2014-15, which has climbed to $3878 \mathrm{Mt}$ in 2019-20. In India, a high concentration of 2, 4-D amine salts is used as a weedicide (herbicide). Its usage was 1MT in 2014-15, but it increased to 1067 MT in 2019-20. Zinc phosphide has been the most often used rodenticide, with consumption ranging from 65 to 200 MT from 2014 to 2020 GOI (2020).

The most often used insecticides are organophosphates, followed by neonicotinoids and pyrethroids. According to one study, cotton is the most pesticideconsuming agri-product (93.27 percent), followed by vegetables ( 87.2 percent), wheat (66.4 percent), millet (52.6 percent), and mustard (12.6 percent ) (Maurya and Malik, 2016; Yadav and Dutta, 2019; Nayak et al., 2020)

\section{PESTICIDES CONSUMPTION SCENARIO}

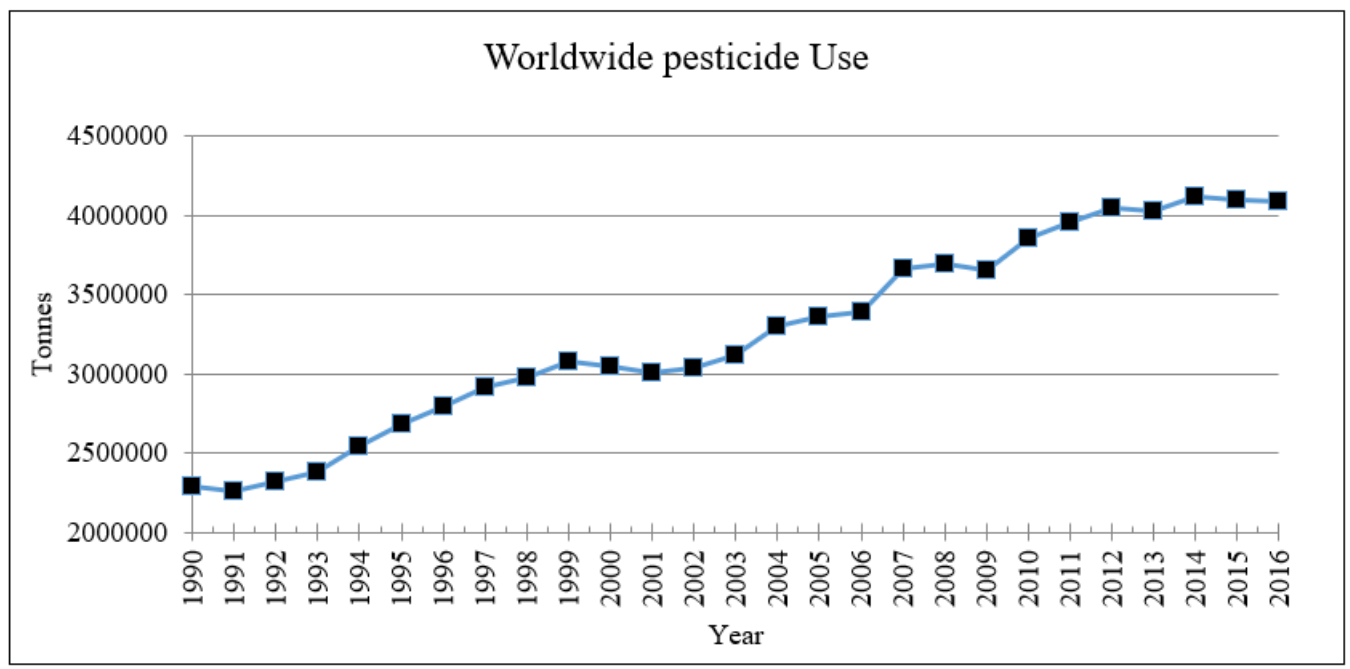

Figure 3 Worldwide Pesticide consumption (1990 to 2016) (Source: http://www.fao.org/faostat/ en/\#data/RP/visualize)

Pesticide production in India began in 1952 with the development of a facility for the manufacturing of BHC in Calcutta, and India is today Asia's second largest maker of pesticides after China, ranking twelfth internationally Mathur and Tannan 


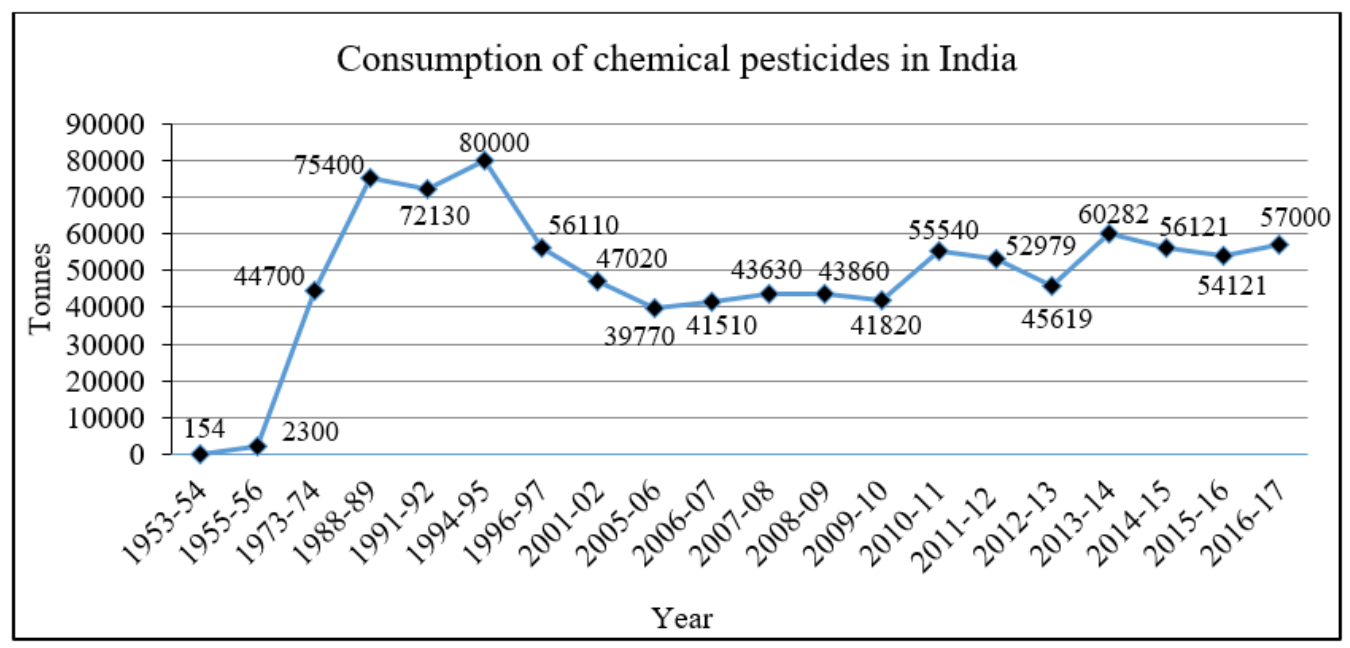

Figure 4 Pesticide consumption in India (1954 to 2017) (Source: http://www.fao.org/faostat/en/ \#data/RP, Chand and Birthal (1997))

(1999); FAO (2018). In India, there has been consistent rise from 5,000 metric tonnes in 1958 to 102,240 metre tonnes in 1998 in the manufacturing of technical grade pesticides. Pesticide demand was anticipated to be at Rs. 22 billion (USD 0.5 billion) in 1996-97, accounting for around 2\% of the overall global market Kumar (2013).

According to the graph, pesticide usage in India has surged hundreds of times over the previous seven decades, from 154 MT in 1953-54 to 57,000 MT in 201617. In 1994-1995, India used the most pesticides (80,000 MT) in a single year Chand and Birthal (1997); Agnihotri (2000); Chelliah et al. (2007); FAO (2018). Due to a prohibition or limit on using organochlorine pesticides, including HCH (BHC), DDTaldrin etc, and the decrease was recorded between 2000 and 2010. One of the reasons for reducing pesticide usage is the adoption of the Stockholm Convention with high levels of application and the development of integrated pesticides management programmes Mansouri et al. (2017); van den Berg et al. (2017).

Pesticide application in India is hampered by the use of low-grade pesticides and a lack of information about pesticide use. Pesticide usage without sufficient restrictions has resulted in a rise in pesticide residue identified in food items in India, according to the Economic Survey 2015-16 Upadhyay and Nishant (2016); Grewal et al. (2017)

During 2016-17, Maharashtra had the highest total pesticide consumption, followed by Uttar Pradesh, Punjab, and Haryana. While Punjab had the greatest per acre pesticide consumption $(0.74 \mathrm{~kg})$, followed by Haryana $(0.62 \mathrm{~kg})$, and Maharashtra $(0.57 \mathrm{~kg})$. According to the data (Figure 5 ), Maharashtra and Uttar Pradesh account for $41 \%$ of India's pesticide consumption. More than $70 \%$ of crop protection chemicals are used in India by the top six states combined. 


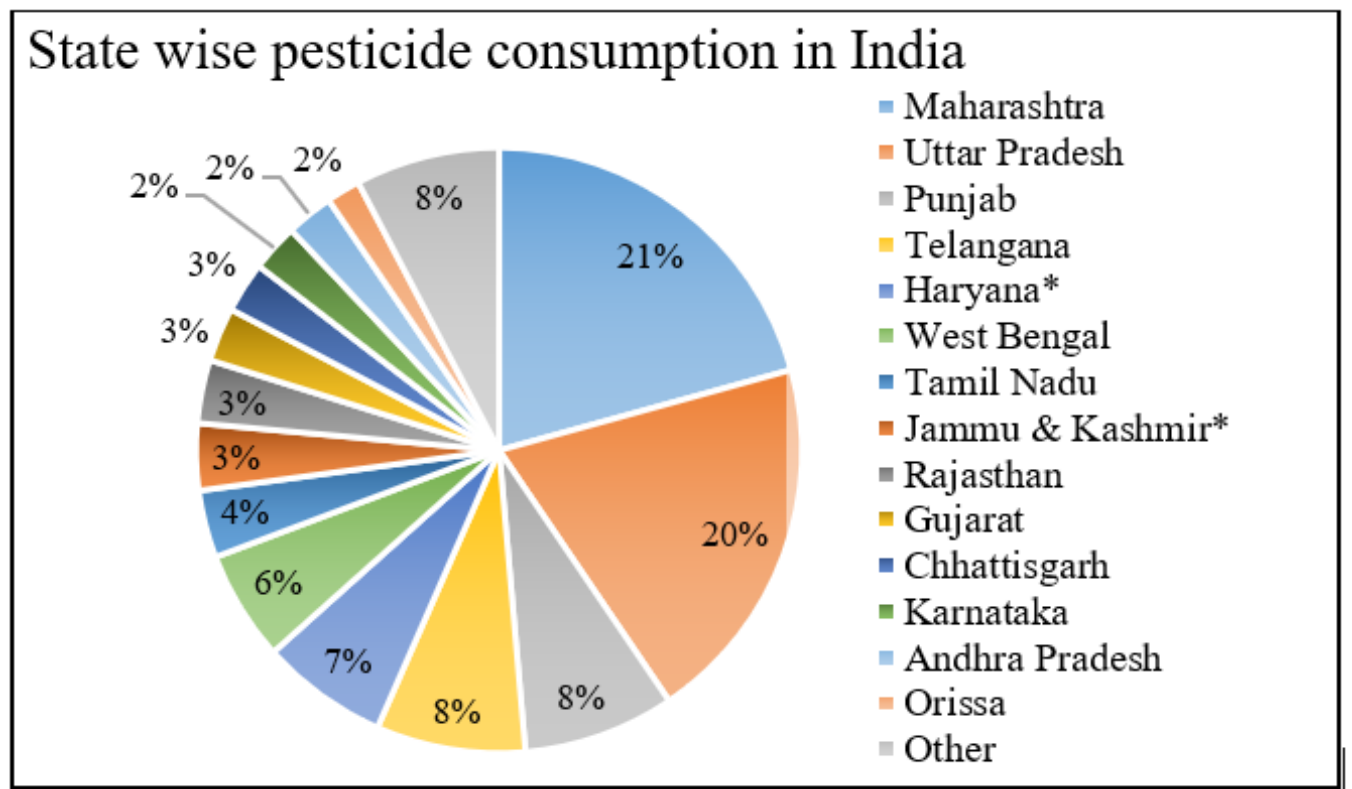

Figure 5 State wise pesticide consumption in India (2019-2020) (Source: GOI (2020))

In these days, many individuals prefer natural alternatives to synthetic chemicals with a greater concern for the environment and for their own health. Because of the benefits related with environmental safety, target-specificity, efficacy, biodegradability, and applicability in integrated pest management (IPM) programmes, biopesticide is gaining popularity. The potential environmental safe application of biopesticides is well known. In view of increased requests for organic food, attention has been gaining Kumar and Singh (2015).

Pesticides derived from natural resources such as plants, animals, microbes, and certain minerals are known as biopesticides. Included in biopesticides are natural pests (Biochemical Pesticides), pesticide control (Microbial Pesticides) microorganisms and regulators of biochemical plant growth. Biopesticides have come a long way from the time of the emergence and general usage of more harmful synthetic pesticides to control agriculture as early as the 17th century Koul (2011); Villaverde et al. (2016); Samada and Tambunan (2020).

The graph (Figure 6 ) depicts changes in the use of chemical and biological insecticides during the last six years. In India, bio-pesticide consumption accounts for about $9 \%$ of overall pesticide consumption. Bio pesticides are being used less frequently. However, data indicate that biopesticide use has surged in India during the previous few decades. Consumption of neem, one of India's most widely used biopesticides, increased from 83 metric tonnes (MT) in 1994-1995 to 686 MT in 1999-2000, while consumption of Bacillus thuringiensis (Bt) climbed from 40 to 71 MT during the same period. The standing committee on chemicals and fertilisers submitted a report on pesticide production and availability in India during the 15th 


\section{Chemical and Bio-pesticide consumption in India}

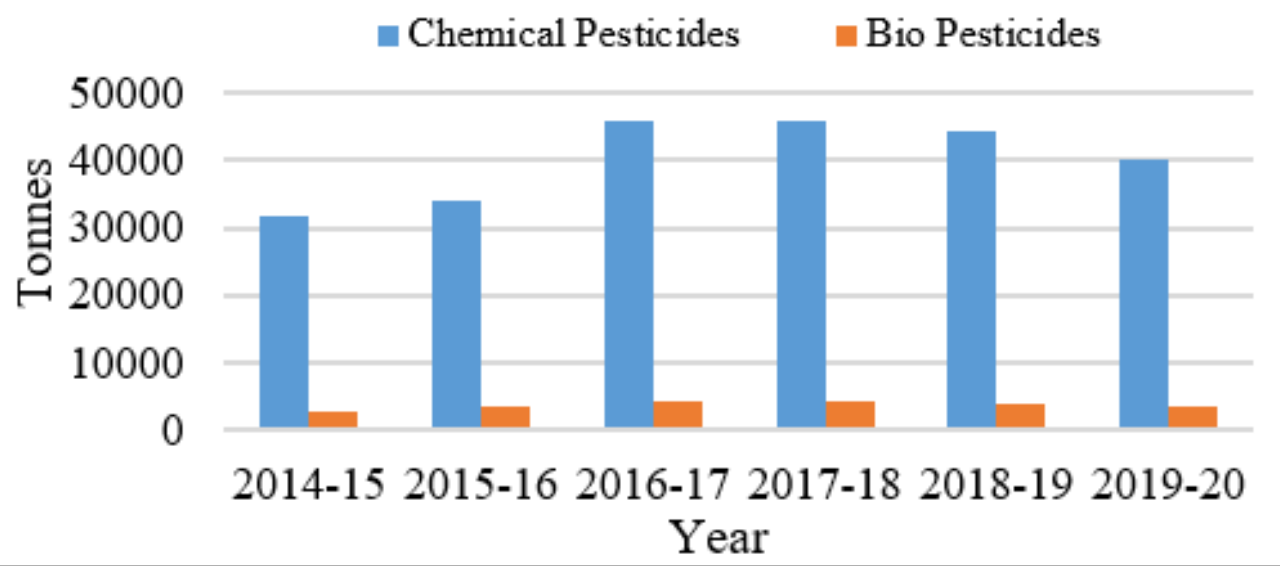

Figure 6 Chemical and Bio pesticide consumption of last six years in India (Source: GOI (2020))

Lok Sabha (2012-2013). According to that report, biopesticide use expanded significantly from 123 metric tonnes (MT) in 1994-1995 to 8110 MT in 2011-2012, far above predictions Mishra et al. (2020). According to PPQS data, the overall consumption of biopesticides in India increased by 40\% from 2014-2015 to 2018-2019. GOI (2020).

There are currently 970 biopesticide products registered with the Central Insecticides Board and Registration Committee (CIBRC), which is the key governing organisation in India for all sorts of biopesticide usage Wickramaarachchi et al. (2017); Mishra et al. (2020); Tripathi et al. (2020). Bacterial, fungal, viral, and other (plant-based, pheromones) biopesticides account for 29, 66, 4, and 1 percent of total biopesticide production, respectively Mishra et al. (2020).

In comparison to other products such as bioherbicides, biofungicides, and bionematicides, bioinsecticides continue to be in high demand. Bioinsecticides account for about 70 percent of the market, with special focus on that category for manufacturers, providing greater control and food safety market (2021).

In India, only 12 different kinds of biopesticides under the Insecticide Act of 1968 have been recorded Kandpal (2014). The main biopesticides manufactured and used in India are Neem-based insecticides, Bacillus thuringensis, NPV, and Trichoderma. While the register for use as chemical pesticides is greater than 230 synthetics K. Sharma et al. (2018). According to Figure 6, Tricoderma, Psedomonas, and NPV-H (nuclear polyhedrosis virus of Helicoverpa armigera) are the most often used insecticides in 2019-20. Most biopesticides, except some used in agriculture, are employed in public health. Besides transgenic plants and beneficial organisms known as bio-agents are also used for pest management in India. Deevi and Biswas (2011). 


\section{Most consumed Bio-pesticides in Indian agriculture}

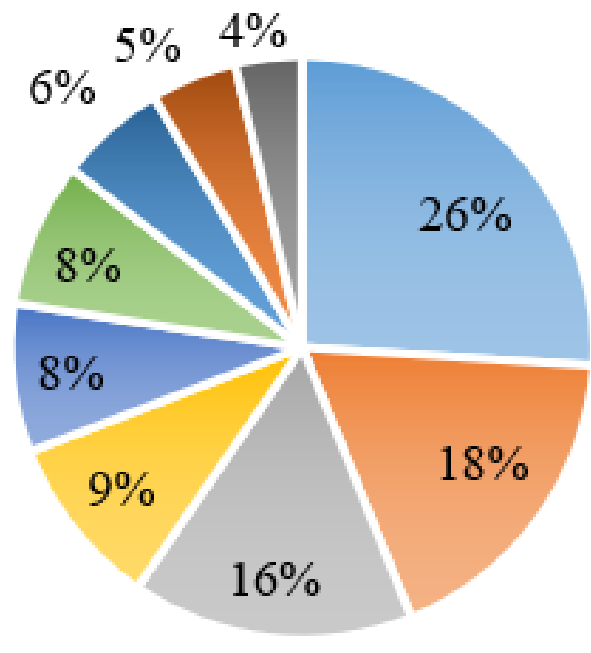

- Tricoderma Viride

- Pseudomonas fluorescens

- NPV (H)

- Tricoderma Spp.

- Neem based insecticides

- Beauveria Bassiana

- Azadirachin

- Verticillium lecanii

- Bacillus Thuringiensis

Figure 7 Most consumed bio-pesticides in India (2019-20) (Source: GOI (2020))

When chemical pesticides failed to eradicate Helicoverpa armigera, Spodoptera litura, and other cotton pests in India, a significant technological breakthrough in the field of biocontrol occurred Kranthi et al. (2002). It was found that biocontrol is the only technology that can be used to control the widespread resistance of chemical pesticides to pest insects in a safe, cost-effective, and environmentally beneficial manner. Biopesticides were later included in IPM, which had previously relied only on the application of chemical pesticides Samada and Tambunan (2020); Mishra et al. (2020).

\section{CONCLUSION}

For more than 60 years, pesticides have been regarded a rapid, convenient, and lowcost alternative for managing weeds and insect pests in agriculture, public health, and other sectors in India. It is established that pesticides have contributed significantly in increasing agricultural production and the farmers' income globally. India has become self-sufficient in production of pesticides and also an important exporter of pesticides. More than 50\% of the pesticides used in India are of insecticides. Chlorpyriphos insecticide has been utilized in highest amount compared to other insecticides. Average chemical pesticide consumption noted around 55000 tonnes/year during 2014-2018 while average bio-pesticides consumption observed around 3500 tonnes/year during 2014-2019. Maharashtra and Uttar Pradesh, both states of India occupies total $40 \%$ of segment in pesticide use. Trichoderma viride is the most fre- 
quently utilised species in the Indian biopesticide industry, having been utilised on 87 different crops, 70 soil-borne diseases, and 18 foliar diseases, respectively. Biopesticides can help farmers transition away from chemical pesticides and toward more dependable, sustainable, and environmentally friendly options. It is proposed that the commercial and public sectors work together to help farmers at the grassroots level by developing an integrated policy and supporting guidelines for the use of bio-pesticides and chemical pesticides.

\section{REFERENCES}

Agnihotri, N. (2000). Pesticide Consumption in Agriculture in India - an Update. Pestic. Res. Journa, 150-155.

Akashe, M. M., Pawade, U. V., \& Nikam, A. V. (2018). CLASSIFICATION OF PESTICIDES: A REVIEW. International Journal of Research in Ayurveda and Pharmacy, 9(4), 144-150. Retrieved from https://dx.doi.org/10.7897/2277-4343.094131 10.7897/2277-4343 .094131

Birthal, P. S., \& Sharma, O. P. (2004). Integrated Pest Management in Indian Agriculture. Proceeding, 11.

Buchel, K. (1983). Chemistry of Pesticides. New york, USA: John Wiley \& Sons.

Carriger, J. F., Rand, G. M., Gardinali, P. R., Perry, W. B., Tompkins, M. S., \& Fernandez, A. M. (2006). Pesticides of Potential Ecological Concern in Sediment from South Florida Canals: An Ecological Risk Prioritization for Aquatic Arthropods. Soil and Sediment Contamination: An International Journal, 15(1), 21-45. Retrieved from https://dx.doi.org/ 10.1080/15320380500363095 10.1080/15320380500363095

Chand, R., \& Birthal, P. S. (1997). Pesticide Use in Indian Agriculture in Relation to Growth in Area and Produciton and Technological Change. Indian J. Agric. Econ, 52.

Chelliah, R. J., Appasamy, P. P., Sankar, U., \& Pandey, R. (2007). Ecotaxes on Polluting Inputs and Outputs. In and others (Ed.), Academic Foundation.

Deevi, K. C., \& Biswas, S. (2011). Organic Input Production and Marketing in India Efficiency. Issues and Policies(239).

Dhaliwal, G. S., Jindal, V., \& Mohindru, B. (2015). Crop Losses due to insect pests: Global and Indian Scenario. Indian Journal of Entomology, 77(2), 165-165. Retrieved from https: / dx.doi.org/10.5958/0974-8172.2015.00033.4 10.5958/0974-8172.2015.00033.4

FAO. (2018). Pesticide Use Data-FAOSTAT. Retrieved from http://www.fao.org/faostat/en/ \#data/RP

Freedman, B. (2018). Environmental Science. 6th ed. Dalhousie University Libraries Digital Editions.

Gilbert, S. (2012). A Small Dose of Toxicology: The Health Effects of Common Chemicals. Boca Raton, FL, USA: Healthy World Press.

Gill, H. K., \& Garg, H. (2014). Pesticides: Environmental Impacts and Management Strategies. In and others (Ed.), Pesticides - Toxic Aspects. IntechOpen. https://doi.org/10.5772/ 57399

GOI. (2020). Statistical Database / Directorate of Plant Protection, Quarantine \& Storage / GOI. Retrieved from http://ppqs.gov.in/statistical-database

Goi. (2021). Insecticides / Pesticides Registered under section 9(3) of the Insecticides Act, 1968 for use in the Country:(As on 01.03.2021).

Green, J. (2018). Sixty years of being A Little Out There. Independently Published. 
Grewal, A. S., , Singla, A., Kamboj, P., \& Dua, J. S. (2017). Pesticide Residues in Food Grains, Vegetables and Fruits: A Hazard to Human Health. Journal of Medicinal Chemistry and Toxicology, 2(1), 40-46. Retrieved from https://dx.doi.org/10.15436/2575-808x.17.1355 10.15436/2575-808x.17.1355

Hassaan, M. A., \& Nemr, A. E. (2020). Pesticides pollution: Classifications, human health impact, extraction and treatment techniques. The Egyptian Journal of Aquatic Research, 46(3), 207-220. Retrieved from https://dx.doi.org/10.1016/j.ejar.2020.08.007 10 .1016/j.ejar.2020.08.007

Kandpal, V. (2014). Biopesticides. Res. India Publ, 4, 190-196.

Koul, O. K. O. (2011). Microbial biopesticides: opportunities and challenges. CAB Reviews: Perspectives in Agriculture, Veterinary Science, Nutrition and Natural Resources, 6(056). Retrieved from https://dx.doi.org/10.1079/pavsnnr20116056 10.1079/ pavsnnr20116056

Kranthi, K. R., Jadhav, D. R., Kranthi, S., Wanjari, R. R., Ali, S. S., \& Russell, D. A. (2002). Insecticide resistance in five major insect pests of cotton in India. Crop Protection, 21(6), 449-460. Retrieved from https://dx.doi.org/10.1016/s0261-2194(01)00131-4 10.1016/s0261-2194(01)00131-4

Kumar, S. (2013). Use of pesticides in agriculture and livestock animals and its impact on environment of India. ASIAN JOURNAL OF ENVIRONMENTAL SCIENCE, 8(1), 51-57.

Kumar, S., \& Singh, A. (2015). Biopesticides: Present Status and the Future Prospects. J. Fertil. Pestic, 6.

Mansouri, A., Cregut, M., Abbes, C., Durand, M.-J., Landoulsi, A., \& Thouand, G. (2017). The Environmental Issues of DDT Pollution and Bioremediation: a Multidisciplinary Review. Applied Biochemistry and Biotechnology, 181(1), 309-339. Retrieved from https://dx.doi.org/10.1007/s12010-016-2214-5 10.1007/s12010-016-2214-5

market, B. (2021). Global Market Study on Biopesticides: The Growing Focus on Sustainable and Organic Agriculture. Persistence Mark. Res.. Retrieved from https://www .persistencemarketresearch.com/market-research/biopesticides-market.asp

Mathur, S., \& Tannan, S. (1999). Future of Indian pesticides industry in next millennium. Pestic. Inf , 24, 9-23.

Maurya, P. K., \& Malik, D. S. (2016). Bioaccumulation of Xenobiotics Compound of Pesticides in Riverine System and Its Control Technique: A Critical Review. J. Ind. Pollut. Control, 32.

Mishra, J., Dutta, V., \& Arora, N. (2020). Biopesticides in India: technology and sustainability linkages. 3 Biotech 10. https://doi.org/10.1007/s13205-020-02192-7

Mooventhan, P., Murali, R. B., Kumar, J., \& Kaushal, P. (2020). NIBSM Publ.

Nations, U. (2019). World population prospects Highlights, 2019 revision Highlights, 2019 revision.

Nayak, S., Sahoo, A., Kolanthasamy, E., \& Rao, K. (2020). Retrieved from https://doi.org/10 .26832/aesa-2020-edcrs-03

OERKE, E. C. (2006). Crop losses to pests. The Journal of Agricultural Science, 144(1), 31-43. Retrieved from https://dx.doi.org/10.1017/s0021859605005708 10.1017/ s0021859605005708

Popp, J., Pető, K., \& Nagy, J. (2013). Pesticide productivity and food security. A review. Agronomy for Sustainable Development, 33(1), 243-255. Retrieved from https://dx.doi.org/ 10.1007/s13593-012-0105-X 10.1007/s13593-012-0105-X

Prabha, S., Yadav, A., Kumar, A., Yadav, A., Yadav, H., Kumar, S., Yadav, R., \& Kumar, R. (2017). WWW Document. 
Roser, M. (2019). Pesticides. Our World Data.

Samada, L. H., \& Tambunan, U. S. F. (2020). Biopesticides as Promising Alternatives to Chemical Pesticides: A Review of Their Current and Future Status. OnLine Journal of Biological Sciences, 20(2), 66-76. Retrieved from https://dx.doi.org/10.3844/ojbsci.2020.66.76 10.3844/ojbsci.2020.66.76

Savary, S., Willocquet, L., Pethybridge, S. J., Esker, P., McRoberts, N., \& Nelson, A. (2019). The global burden of pathogens and pests on major food crops. Nature Ecology \& Evolution, 3(3), 430-439. Retrieved from https://dx.doi.org/10.1038/s41559-018-0793-y 10.1038/s41559-018-0793-y

Sharma, A., Kumar, V., Shahzad, B., Tanveer, M., Sidhu, G. P. S., Handa, N., Kohli, S. K., Yadav, P., Bali, A. S., Parihar, R. D., Dar, O. I., Singh, K., Jasrotia, S., Bakshi, P., Ramakrishnan, M., Kumar, S., Bhardwaj, R., \& Thukral, A. K. (2019). Worldwide pesticide usage and its impacts on ecosystem. SN Appl. Sci, 1. https://doi.org/10.1007/s42452-019-1485-1

Sharma, K., Raju, S., Kumar, D., \& Thakur, S. (2018). Biopesticides: an effective tool for insect pest management and current scenario in India.

TAAS. (2020). (Trust for Advancement of Agricultural Sciences), SPS, (Society of Pesticide Science), IPS, (Indian Phytopathological Society), ESI, (Entomological Society of India), 2020. Stakeholders Dialogue on Current Challenges and Way Forward for Pesticides Management - A Road Map. Indian Phytopathological Society.

Tripathi, Y. N., Divyanshu, K., Kumar, S., Jaiswal, L. K., Khan, A., Birla, H., Gupta, A., Singh, S. P., \& Upadhyay, R. S. (2020). Biopesticides: Current Status and Future Prospects in India (Keswani \& C., Eds.). Singapore; Singapore: Springer. Retrieved from https://doi.org/ 10.1007/978-981-13-9431-7_6

Tudi, M., Ruan, H. D., Wang, L., Lyu, J., Sadler, R., Connell, D., Chu, C., \& Phung, D. T. (2021). Agriculture Development, Pesticide Application and Its Impact on the Environment. International Journal of Environmental Research and Public Health, 18(3), 1112-1112. Retrieved from https://dx.doi.org/10.3390/ijerph18031112 10.3390/ ijerph18031112

Upadhyay, R., \& Nishant, N. (2016). Presence of pesticide residue in vegetable crops: A review. Agricultural Reviews, 37(3), 173-185. Retrieved from https://dx.doi.org/10.18805/ag .v37i3.3533 10.18805/ag.v37i3.3533

van den Berg, H., Manuweera, G., \& Konradsen, F. (2017). Global trends in the production and use of DDT for control of malaria and other vector-borne diseases. Malaria Journal, 16(1). Retrieved from https://dx.doi.org/10.1186/s12936-017-2050-2 10.1186/ s12936-017-2050-2

Villaverde, J. J., Sandín-España, P., Sevilla-Morán, B., López-Goti, C., \& Alonso-Prados, J. L. (2016). Biopesticides from Natural Products: Current Development, Legislative Framework, and Future Trends. BioResources, 11(2), 5618-5640. Retrieved from https:// dx.doi.org/10.15376/biores.11.2.villaverde 10.15376/biores.11.2.villaverde

Who. (n.d.).

WHO. (2019). Global situation of pesticide management in agriculture and public health: report of a 2018 WHO-FAO survey. World Health Organization.

Wickramaarachchi, W. A. R. T., Chaudhary, M., \& Patil, J. (2017). Facilitating microbial pesticide use in agriculture in South Asia. Presented at the SAARC Regional Expert Consultation on Facilitating Microbial Pesticide Use in Agriculture in South Asia. National Bureau of Agricultural Insect Resources.

Yadav, I., \& Devi, N. (2017). Pesticides Classification and Its Impact on Human and Environment. Environ. Sci. \& Engg. Vol. 6: Toxicology, 140-158. Retrieved from 
https://www.researchgate.net/profile/Ishwar-Yadav/publication/313445102

_Pesticides_Classification_and_Its_Impact_on_Human_and_Environment/links/ 589b09a04585158bf6fb8080/Pesticides-Classification-and-Its-Impact-on-Human -and-Environment.pdf

Yadav, S., \& Dutta, S. (2019). A Study of Pesticide Consumption Pattern and Farmer's Perceptions towards Pesticides: A Case of Tijara Tehsil, Alwar (Rajasthan). International Journal of Current Microbiology and Applied Sciences, 8(04), 96-104. Retrieved from https://dx.doi.org/10.20546/ijcmas.2019.804.012 10.20546/ijcmas.2019.804.012 